\title{
PENERAPAN STRATEGI TRAINING WITHIN INDUSTRY DALAM PEMBELAJARAN MENGOPERASIKAN SISTEM PENGENDALI ELEKTROMAGNETIK
}

\author{
Dhea Fatmadilla $^{1 *}$, Usmeldi ${ }^{1}$, Krismadinata ${ }^{1}$ \\ ${ }^{1}$ Jurusan Teknik Elektro, Fakultas Teknik, Universitas Negeri Padang \\ *e-mail: dfatmadilla@gmail.com
}

\begin{abstract}
Abstrak- Penelitian ini bertujuan untuk melihat hasil unjuk kerja siswa dengan strategi Training Within Industry (TWI) menggunakan instrumen penilaian unjuk kerja pada mata pelajaran Mengoperasikan Sistem Pengendali Elektromagnetik (MSPEM) kelas XI TITL 1 SMK Muhammadiyah 1 Padang. Jenis penelitian ini adalah penelitian deskriptif yang dilaksanakan secara Quasi Experiment. Subjek pada penelitian ini adalah siswa kelas XI TITL 1 SMK Muhammadiyah 1 Padang yang terdiri dari 32 orang siswa. Pada penelitian ini, metode pengumpulan data dengan menggunakan penilaian kinerja berupa rubrics yang divalidasi oleh penimbang ahli. Data yang diperoleh diolah dalam bentuk deskriptif. Berdasarkan hasil penelitian ditemukan bahwa siswa telah mencapai nilai KKM yang telah ditetapkan yaitu 80. Hal ini dibuktikan dengan perolehan rata-rata dari skor penilaian kinerja dengan presentase $85 \%$ sudah mencapai ketuntasan dari nilai KKM yang ditentukan dan berdasarkan kategori yang diperoleh melalui skor penilaian kinerja sebanyak 27 dari 32 siswa berada pada kategori sangat tinggi. Dengan demikian dapat disimpulkan bahwa terdapat peningkatan hasil unjuk kerja dalam penerapan Strategi TWI, dan memberikan pegaruh positif pada siswa dengan menjadi aktif dalam pembelajaran, meningkatkan kinerja siswa dalam menyelesaikan praktikum yang dibuat maupun kemandirian dan kedisiplinan di SMK Muhammadiyah 1 Padang.
\end{abstract}

Kata Kunci: Strategi Training Within Industry, Hasil Unjuk Kerja, MSPEM

Abstract- This study aims to investigate the improvement of student performance applying strategy Training Within Industry (TWI) using competence assessment in the class XII TITL 1 SMK Muhammadiyah 1 Padang. It was a Descriptive research that to do on a Quasi Experiment. The subjects were students of XI TITL 1 SMK Muhammadiyah 1 Padang with 32 students. The data was collected by using competence assessment in the form of rubrics that validated by expert judgement. Based on the results, it found that students have reached the KKM score of 80 . This is evidenced by the result of competence assessment scores with a percentage of $85 \%$ has reached the completeness KKM is and based on the categories which is determined, there are 27 of 33 students in very high category. So, it can be concluded that there is an enhancement in learning result by TWI, provide positive effect by being active in learning, to improve student competence in completing the project created and discipline in SMK Muhammadiyah 1 Padang.

Key Word: strategy Training Within Industry, student performance, MSPEM

Copyright @ 2017 INVOTEK. All rights reserved

\section{PENDAHULUAN}

Mata pelajaran Mengoperasikan Sistem Pengendali Elektromagnetik (MSPEM) merupakan salah satu mata pelajaran kelompok produktif yang diajarkan pada kelas XI TITL yang aplikasinya banyak digunakan di industriindustri manufaktur. Dengan menguasai seluruh keterampilan-keterampilan yang diajarkan pada setiap mata pelajaran praktik diharapkan tamatan SMK mampu memenuhi tuntutan dunia kerja yang terus berkembang. Namun, di beberapa
SMK terdapat berbagai permasalahan atau kesenjangan dalam mata pelajaran MSPEM seperti, di SMK Negeri 2 Sijunjung didapat bahwa pembelajaran MSPEM cenderung susah dipahami oleh beberapa siswa, Selain materinya yang cukup sulit, terkadang penyampaian materi oleh guru terkesan membosankan dan tidak menarik perhatian siswa [3]. Sedangkan di SMKN 2 Payakumbuh, dalam pembelajaran MSPEM masih banyak siswa yang melakukan praktikum tanpa mematuhi prosedur atau langkah-langkah jalannya praktikum [8]. Di SMKN 5 Padang, 
Metode yang diterapkan selama ini belum membuat siswa aktif sehingga pembelajaran MSPEM menjadi monoton [4]. Di SMKN 1 Padang, sebagian siswa mengganggap bahwa praktik SPEM menyulitkan dan terlalu banyak kabel [6] [7].

Berdasarkan hasil pengamatan di kelas XI TITL SMK Muhammadiyah 1 Padang pada mata pelajaran MSPEM, juga terdapat beberapa kesenjangan dalam pembelajaran diantaranya: (1) Pembelajaran yang dilakukan masih berpusat pada guru, jadi guru lebih banyak mendominasi pembelajaran dari pada siswanya, (2) Masih banyak siswa yang tidak mampu membaca hasil pengukuran pada multimeter saat melakukan praktik sehingga siswa tidak bisa membedakan kondisi komponen yang masih baik atau telah rusak, (3) Sebagian siswa menganggap bahwa praktik MSPEM menyulitkan dan terlalu banyak kabel, (4) Siswa terbiasa bekerja tidak terstruktur dan seringkali terfokus pada hasil akhir sehingga mengabaikan proses. Sementara dalam melaksanakan praktik, seluruh proses yang dilakukan lebih menentukan baik atau tidaknya hasil yang dicapai. (5) Mata pelajaran MSPEM tidak dipahami secara mendalam oleh siswa sehingga hasil belajar siswa banyak yang belum mencapai KKM. Dari permasalahan tersebut, diperlukan strategi pembelajaran yang tepat untuk membuat peserta didik paham baik secara kognitif sekaligus psikomotor dan tentunya strategi pembelajaran yang mudah dipahami oleh para siswa. Untuk mengajarkan praktik keterampilan kejuruan perlu digunakan strategi tertentu agar siswa paham, salah satu strategi pembelajaran untuk mengajarkan keterampilan dasar kejuruan adalah strategi Training Within Industry [10]. Penerapan strategi Training Within Industry dalam proses pembelajaran praktik di sekolah memandu siswa untuk belajar bekerja secara bertahap, berurutan dan mengikuti prosedur kerja standar untuk menguasai suatu keterampilan kerja. Di mana siswa tidak bisa lanjut ketahap berikutnya sampai tahap sebelumnya dikuasai.

Strategi pembelajaran TWI memiliki keunggulan tersendiri dibandingkan pembelajaran yang biasanya dilakukan oleh guru dalam melaksanakan pembelajaran. Selain untuk meningkatkan keterampilan dan pemahaman siswa dalam melaksanakan praktik, siswa juga dituntut untuk menjadi contoh bagi siswa-siswa lainnya. Siswa memperagakan praktik dengan benar sesuai prosedur di hadapan siswa lainnya dan guru pembimbing. Selain itu strategi pembelajaran TWI juga mengatur sikap hubungan kerja sesama teman. Adanya interaksi dan saling melengkapi satu sama lain membuat pemahaman materi pada siswa menjadi lebih cepat. Sehingga tidak ada siswa yang bermain-main dalam praktik dan mengandalkan teman yang lebih aktif.

\section{STUDI PUSTAKA}

\subsection{Belajar dan Pembelajaran}

Belajar adalah sebuah proses perubahan di dalam kepribadian manusia dan perubahan tersebut ditampakkan dalam bentuk peningkatan kualitas dan kuantitas tingkah laku seperti peningkatan kecakapan, pengetahuan, sikap, kebiasaan, pemahaman, keterampilan, daya pikir, dan kemampuan-kemampuan yang lain. Dalam proses pengajaran, unsur proses belajar memegang peranan yang penting. Pembelajaran secara sederhana dapat diartikan sebagai produk interaksi berkelanjutan antara pengembangan dan pengalaman hidup. Pembelajaran dalam makna kompleks adalah usaha sadar dari seorang guru untuk mendidik siswanya (mengarahkan interaksi siswa dengan sumber belajar lainnya) dalam rangka mencapai tujuan yang diharapkan [6].

Dari penjelasan sebelumnya maka belajar merupakan suatu kegiatan yang atau proses perubahan pribadi seseorang dengan memperteguh perlakuan dan pengetahuan memalui pengalaman. Sedangkan pembelajaran merupakan suatu sistem yang terdiri dari unsur unsur yang saling berkaitan dengan yang lain yang saling mempengaruhi tercapainya suatu tujuan pembelajaran.

\subsection{Strategi Pembelajaran Ranah Psikomotorik}

Beberapa strategi pembelajaran yang biasa di gunakan dalam pembelajaran ranah psikomotorik adalah sebegai berikut : (1) Pembelajaran berbasis proyek, (2) strategi pembelajaran model pelatihan, (3) strategi pembelajaran pelatihan laboratorium, (4) Strategi Training Within Industry (TWI) (4) metode demonstrasi. Dari beberapa startegi pembelajaran yang ada, ,maka dalam penelitian ini didpilih strategi TWI untuk menegtahui hasil unjuk kerja siswa dalam pemebelajaran MSPEM.

Penerapan TWI memiliki keunggulan tersendiri dibandingkan dengan penerapan metode pembelajaran yang umumnya digunakan dalam pembelajaran praktik. Metode yang umum digunakan dalam pembelajaran praktik adalah metode demonstrasi dan praktik langsung hanya sekali oleh siswa dalam kelompok kerjasedangkan pada strategi TWI proses pembelajaran merupakan kombinasi metode pembelajaran yaitu 
metode ceramah, metode demonstrasi, latihan atau pengulangan kerja oleh siswa, persentase siswa dihadapan siswa lainnya dan praktik dalam kelompok kerja. Hasil belajar yang dapat dicapai siswa adalah disamping siswa memiliki keterampilan dan melakukan pekerjaan dan sikap kerja sesuai standar kerja, siswa juga memiliki jiwa kepemimpinan dan kepercayaan diri. Jadi terlihat bahwa penerapan strategi TWI dalam pembelajaran melibatkan 3 ranah belajar siswa pada aspek kognitif, afektif, dan psikomotor.

\subsection{Hasil Belajar Mata Pelajaran MSPEM}

Hasil belajar yang diukur pada mata pelajaran MSPEM ini adalah hasil belajar psikomotor. Ranah psikomotor berhubungan dengan hasil belajar yang pencapaiannya melalui keterampilan manipulasi yang melibatkan otot dan kekuatan fisik [5]. Penilaian hasil belajar psikomotor mencakup: (1) kemampuan menggunakan alat dan sikap kerja, (2) kemampuan menganalisis suatu pekerjaan dan menyusun urutan pengerjaan, (3) kecepatan mengerjakan tugas, (4) kemampuan membaca gambar dan atau simbol, (5) keserasian bentuk dengan yang diharapkan dan atau ukuran yang telah ditentukan [5].

\section{METODOLOGI}

Jenis penelitian yang digunakan dalam penelitian ini yaitu deskriptif namun dilaksanakan secara Quasi Experiment. Dalam penelitian ini menggunakan satu kelas sampel, yaitu kelas eksperimen. Pada kelas eksperimen diberi perlakuan berupa pembelajaran dengan strategi TWI dalam pembelajaran Mengoperasikan Sistem Pengendali Elektromagnetik. Desain penelitian digambarkan pada Tabel 1:

\begin{tabular}{l|l|l}
\multicolumn{2}{c}{ Tabel 1. Rancangan Penelitian } \\
\hline Grup & Perlakuan & Hasil \\
Eksperimen & $\mathrm{X}$ & $\mathrm{O}$ \\
\hline Sumber: [8]
\end{tabular}

Keterangan:

$\mathrm{X}=$ Pembelajaran menggunakan strategi TWI

$\mathrm{O}=$ Hasil penilaian kinerja kelas eksperimen

Dalam penelitian ini, subjek penelitiannya yaitu siswa kelas XI TITL 1 tahun ajaran 2016/2017 berjumlah 32 orang. Di SMK Muhammadiyah 1 Padang kelas tersebut dibagi menjadi 2 grup kerja yaitu XI TITL 1 A dengan jumlah 16 orang dan XI TITL 1 B berjumlah 16 orang.

\subsection{Instrumen Penelitian}

Instrumen penelitian merupakan alat untuk pengumpulan data yang digunakan dalam penelitian. Jenis instrumen yang digunakan dalam penelitian ini adalah penilaian unjuk kerja. Penilaian unjuk kerja ini digunakan untuk memperoleh data mengenai hasil belajar praktik MSPEM. Kisi-kisi instrumen penilaian unjuk kerja seperti tabel 2:

Tabel 2. Kisi-kisi penilaian praktik mata pelajaran MSPEM

\begin{tabular}{|c|c|}
\hline $\begin{array}{l}\mathrm{N} \\
\mathrm{O}\end{array}$ & Komponen/ Sub komponen Penilaian \\
\hline \multirow[t]{2}{*}{ I } & $\begin{array}{l}\text { Persiapan Kerja } \\
\text { 1.1. Persiapan alat dan bahan sesuai dengan } \\
\text { kebutuhan }\end{array}$ \\
\hline & $\begin{array}{l}\text { 1.2. Identifikasi dan pemeriksaan bahan dan } \\
\text { peralatan sesuai persyaratan }\end{array}$ \\
\hline II & $\begin{array}{l}\text { Peragaan } \\
\text { 2.1. mendengarkan dan memperhatikan guru } \\
\text { menjelaskan langkah praktikum }\end{array}$ \\
\hline \multirow[t]{8}{*}{ III } & $\begin{array}{l}\text { Peniruan } \\
\text { 3.1. Melakukan peniruan proses kerja }\end{array}$ \\
\hline & $\begin{array}{l}\text { Praktik } \\
\text { 4.1. Penggunaan bahan sesuai kebutuhan. }\end{array}$ \\
\hline & 4.2. Penggunaan alat sesuai fungsinya. \\
\hline & $\begin{array}{l}\text { 4.3. Melakukan praktikum sesuai langkah-langkah } \\
\text { di jobsheet. }\end{array}$ \\
\hline & $\begin{array}{l}\text { 4.4. Pemasangan komponen pada papan kerja } \\
\text { lengkap dan benar. }\end{array}$ \\
\hline & 4.5. Kerapian kerja \\
\hline & 4.6. Rangkaian kontrol dapat dioperasikan \\
\hline & 4.7. Memperhatikan keselamatan kerja \\
\hline \multirow[t]{3}{*}{$\mathrm{V}$} & $\begin{array}{l}\text { Evaluasi } \\
\text { 5.1. Ketepatan waktu melaksanakan praktik }\end{array}$ \\
\hline & $\begin{array}{l}\text { 5.2. Mengembalikan dan membersihkan alat dan } \\
\text { bahan sesuai prosedur }\end{array}$ \\
\hline & 5.3. Laporan lengkap dan benar \\
\hline
\end{tabular}

Sumber: [1].

Validitas dalam penelitian ini adalah validitas isi. Pengkajian validitas pada penilaian kinerja tidak dilakukan melalui analisis statistik, tetapi dengan menggunakan analisis rasional, yaitu dengan menyusun aspek yang akan dinilai pada mata pelajaran Mengoperasikan Sistem Pengendali Elektromagnetik kelas XI TITL 1 sesuai kurikulum dan dimintakan pendapat minimal dua orang penimbang ahli. Pelaksanaan validasi isi menggunakan lembar validasi penilaian kinerja. Hasil validitas isi oleh 
penimbang ahli menunjukkan bahwa instrument layak di gunakan dengan saran memperbaiki pernyataan yang telah di buat. Pernyataan yang dibuat harus pernyataan yang dapat di amati.

\subsection{Teknik Analisis Data}

Data penelitian ini dianalisis secara deskriptif. Metode analisis data merupakan cara yang digunakan untuk menganalisis atau mengolah data yang telah terkumpul. Penelitian ini merupakan penelitian deskriptif. Penelitian deskriptif merupakan penelitian non hipotesis sehingga dalam langkah penelitian tak memerlukan hipotesis [2]. Untuk mengetahui kecenderungan hasil pengukuran digunakan kriteria penilaian yang dibedakan menjadi lima kategori, yaitu: Sangat Tinggi : skor $\geq \mathrm{M}$ ideal $+1,5 \mathrm{SD}$ ideal Tinggi : $\mathrm{M}$ ideal + 0,5 SD ideal $\leq$ skor $<\mathrm{M}$ ideal $+1,5$ SD ideal

Sedang : M ideal $-0,5$ SD ideal $\leq$ skor $<\mathrm{M}$ ideal $+0,5 \mathrm{SD}$ ideal

Rendah : M ideal - 1,5 SD ideal $\leq$ skor $<$ M ideal $-0,5$ SD ideal

Sangat Rendah : skor $<$ M ideal - 1,5 SD ideal Untuk mendapatkan harga M ideal dan SD ideal (standar deviasi ideal), maka digunakan persamaan:

M ideal $=1 / 2($ nilai ideal tertinggi + nilai ideal terendah)

SD ideal $=1 / 6$ (nilai ideal tertinggi - nilai ideal terendah)

\section{HASIL DAN PEMBAHASAN}

\subsection{Deskripsi data}

Pembahasan mengenai deskripsi data ini mengungkapkan informasi tentang mean, median, modus, standar deviasi, range, skor terendah, skor tertinggi, dan jumlah skor yang diperoleh dari hasil pengolahan. Sedangkan perhitungan data yang dipakai menggunakan perhitungan manual. Setelah dilakukan penilaian kinerja maka didapatlah skor terendah 77 dan skor tertinggi 89. Dari data tersebut distribusi skor rata-rata (mean) sebesar 82,68 atau dibulatkan menjadi 83, skor tengah (median) adalah 83, skor yang banyak muncul (modus) adalah 80, dan simpangan baku (standar deviasi) sebesar 12,092. Untuk memperoleh gambaran yang jelas tentang penilaian kinerja dapat dilihat pada tabel 3 :

Tabel 3. Tabulasi persentase penilaian kinerja siswa kelas XI TITL 1

\begin{tabular}{c|l|l|l}
\hline No & Kelas Interval & $\begin{array}{l}\text { Frekuensi } \\
(\mathrm{F})\end{array}$ & Persentase (\%) \\
\hline 1 & $77-78$ & 4 & $12.5 \%$
\end{tabular}

\begin{tabular}{l|l|l|l}
2 & $79-80$ & 6 & $19 \%$ \\
3 & $81-82$ & 5 & $16 \%$ \\
\hline 4 & $83-84$ & 8 & $25 \%$ \\
5 & $85-86$ & 4 & $12.5 \%$ \\
6 & $87-88$ & 3 & $9 . \%$ \\
7 & $89-90$ & 2 & $6 \%$ \\
Jumlah & 32 & $100 \%$ \\
Rata-rata skor & 82,68 & \\
Simpangan Baku & 12,092 & \\
KKM & 80 & \\
\hline
\end{tabular}

Berikut untuk melihat gambaran distribusi frekuensi skor hasil kinerja.

Frekuensi

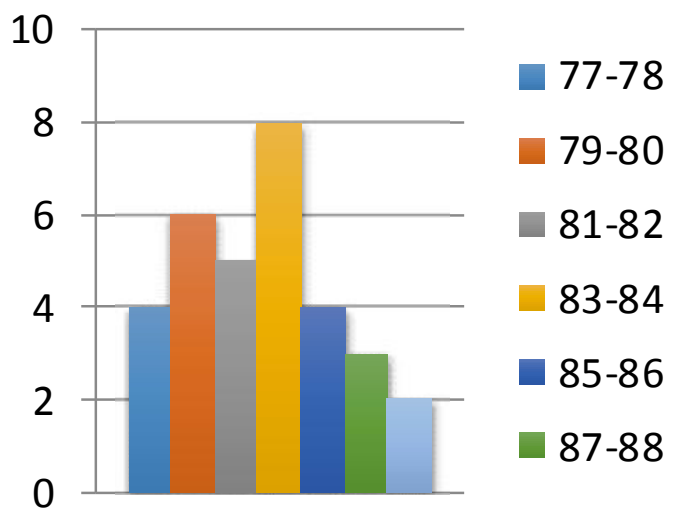

Kelas Interval

Gambar 1. Histogram Penilaian Kinerja Siswa

Kategori penilaian kinerja beserta skor berdasarkan jumlah siswa diperoleh sebagai berikut:

Tabel 4. Kategori Penilaian Kinerja Siswa Kelas XI TITL 1

\begin{tabular}{l|l|l}
\hline Kategori & Skor & Jumlah Siswa \\
\hline Sangat Tinggi & $80-100$ & 27 \\
Tinggi & $67-79$ & 5 \\
Sedang & $53-66$ & 0 \\
Rendah & $40-52$ & 0 \\
Sangat Rendah & $0-40$ & 0
\end{tabular}

\subsection{Pembahasan}

Berdasarkan deskripsi data yang telah dilakukan, diperoleh gambaran seperti pada tabel 4.1 dan 4.2 yang mana dari pembelajaran dengan strategi TWI siswa tentang penilaian kinerja siswa yang mana $85 \%$ siswa memperoleh nilai dengan kategori sangat tinggi dan $15 \%$ siswa memperoleh nilai dengan kategori tinggi. Jika dibandingkan dengan nilai KKM yang telah ditentukan, maka untuk penilaian kinerja, 27 dari 32 siswa tuntas melebihi KKM. Jadi dapat disimpulkan bahwa 
siswa kelas XI TITL di SMK Muhammadiyah 1 Padang tentang kinerja berada dalam kategori tinggi ketuntasan dari nilai KKM yang ditentukan. Dari paparan diatas secara umum telah mampu menjawab rumusan masalah dan mencapai tujuan yang diharapkan. Penelitian ini dapat dikatakan berhasil karena semua kriteria yang ditentukan telah terpenuhi. Hal ini menandakan bahwa dengan penerapan strategi TWI dapat meningkatkan unjuk kerja siswa dalam praktikum serta merubah perilaku siswa menjadi lebih baik dan membangun kemandirian, keaktifan dan kedisiplinan siswa dalam proses pembelajaran Mengoperasikan Sistem Pengendali Elektromagnetik.

\section{KESIMPULAN}

Berdasarkan hasil penelitian dan pembahasan yang telah diuraikan diatas, dapat disimpulkan beberapa hal sebagai berikut:

a. Penerapan strategi TWI pada mata pelajaran

Mengoperasikan Sistem Pengendali

Elektromagnetik siswa kelas XI TITL 1 di

SMK Muhammadiyah 1 Padang dapat meningkatkan kinerja siswa dalam melakukan praktikum, hal itu dapat dilihat dari peningkatan ketuntasan yang diperoleh sebelum diterapkannya dengan setelah diterapkannya strategi TWI.

b. Hasil ujuk kerja siswa kelas XI TITL 1 SMK Muhammadiyah 1 Padang pada mata pelajaran Mengoperasikan Sistem Pengendali Elektromagnetik dengan menerapkan strategi TWI termasuk dalam kategori sangat tinggi dengan presentase $85 \%$ dan sudah mencapai ketuntasan dari nilai KKM yang ditentukan dengan jumlah 32 siswa.

\section{DAFTAR PUSTAKA}

[1] Anggraini Dwi. Penerapan Strategi Pembelajaran Training Within Industry (Twi) Pada Mata Pelajaran Instalasi Penerangan Bangunan Bertingkat Di SMK Negeri 1 Batipuh. Padang: Fakultas Teknik Universitas Negeri Padang (2013)

[2] Arikunto Suharsimi. Dasar-Dasar Evaluasi Pendidikan. Jakarta: Bumi Aksara (2001)

[3] Betri Aidil. Penerapan Media Pembelajaran Interaktif Menggunakan Adobe Flash Pada Mata Pelajaran Mengoperasikan Sistem Pengendali Elektromagnetik Untuk Meningkatkan Hasil Belajar Siswa Kelas XI TITL Di SMKN 2 Sijunjung. Padang:
Fakultas Teknik Universitas Negeri Padang (2016)

[4] Bismi Paradishe. Studi Perbandingan Metode Pembelajaran Kooperatif Tipe Stad Dengan CTL Pada Mata Pelajaran Sistem Pengendali Kelas XI TITL Di SMKN 5 Padang. Padang: Fakultas Teknik Universitas Negeri Padang (2016)

[5] Depdiknas. Pengembangan Perangkat Penilaian Psikomotor. Jakarta: Gramedia (2008)

[6] Hastuti, Hansi Effendi, dan Siti H. Penerapan Trainer PLC Omron Sebagai Media Pembelajaran Mata Diklat Instalasi Motor Listrik. Padang. Jurnal INVOTEK Vol 2, No 1 April 2017.

[7] Hendra Sasfa. Hasil Belajar Siswa Menggunakan Strategi Training Within Industry Pada Mata Pelajaran Sistem Pengendali Elektromagnetik Di SMKN 1 Padang. Padang: Fakultas Teknik Universitas Negeri Padang (2013)

[8] Hudin Rahmad. Penerapan Model Pembelajaran Berbasis Proyek Dalam Pembelajaran Mengoperasikan Sistem Kendali Berbasis Elektromekanik Pada Kelas Xi TOI Di SMKN 2 Payakumbuh. Padang: Fakultas Teknik Universitas Negeri Padang (2014)

[9] Suryabata Sumadi. Metodologi Penelitian. Jakarta: PTRajagrafindoPersada (2003)

[10] Wena,Made. Strategi Pembelajaran Inovatif Kontemporer. Jakarta: PT. Bumi Aksara (2011)

\section{Biodata Penulis}

Dhea Fatmadilla, lahir di Pangkalan, 10 September 1995. Jurusan Teknik Elektro Program Studi Pendidikan Teknik Elektro di Universitas Negeri Padang tahun 2013.

Usmeldi, lahir di Kapau Agam, 10 September 1960. Menyelesaikan studi S1 di IKIP Padang, S2 di IKIP Bandung dan S3 di UPI Bandung. Dosen di Jurusan Teknik Elektro Fakultas Teknik Universitas Negeri Padang sejak tahun 1985sekarang

Krismadinata, lahir di Padang, 11 September 1977. Menyelesaiakan studi S1 di Universitas Andalas, S2 di Institut Teknologi Bandung, dan S3 di Universitas Malaya. Dosen di Jurusan Teknik Elektro Fakultas Teknik Universitas Negeri Padang sejak tahun 2000-sekarang. 
